US Army Corps

of Engineers

Hydrologic Engineering Center

\title{
Runoff Simulation Using Radar Rainfall Data
}

\author{
WATER RESOURCES \\ CENTER ARCHIVES \\ MAR - - 2006 \\ 'INIVERSITY OF CALIFORNI' \\ BERKELEY
}

Technical Paper No. 155

August 1996

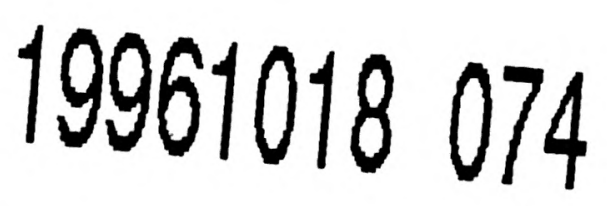

Approved for Public Release. Distribution Unlimited.

DITC QUALTTY INBPRCTTED 8 